\title{
EFFECT OF DIFFERENT LEVELS OF HYDROGEN + LPG ADDITION ON EMISSIONS AND PERFORMANCE OF A COMPRESSION IGNITION ENGINE
}

\author{
Yasin Karagöz ${ }^{1}$, Hasan Köten ${ }^{2, *}$
}

\begin{abstract}
Compelling emission regulations and diesel engines damage on environment have led researchers to work on alternative fuels such as LPG and hydrogen in recent years. Diesel engine costs are also increasing, especially on the increased costs of after-treatment equipment used in diesel engines. It is also known that diesel engines release $\mathrm{NO}_{\mathrm{x}}$ and smoke emissions, which are highly harmful to the environment and to the living health. The effect of the emissions of $\mathrm{LPG}+\mathrm{H}_{2}(0 \%, 15 \%, 30 \%$ and $45 \%)$ with different energy contents at full load and same torque $(70 \mathrm{Nm})$ at constant engine speed of $1200 \mathrm{rpm}$ is investigated on $\mathrm{CO}, \mathrm{THC}, \mathrm{NO}_{\mathrm{x}}$ and Smoke emissions. From the results obtained, there was a slight increase in brake thermal efficiency, $\mathrm{CO}$ and THC emissions. However, significant improvement in $\mathrm{NO}_{\mathrm{x}}$ and smoke emissions has been achieved. The results show that using LPG $+\mathrm{H}_{2}$ in diesel engines, older technology and lower cost after-treatment equipment can be used, and that $\mathrm{NO}_{\mathrm{x}}$ and smoke emissions of diesel engines can be reduced significantly. Also, using small amount of hydrogen ( $20 \%$ of total gas mixture) and LPG, an important improvement can be achieved, and the harmful effects of diesel engines can be suppressed thanks to unique properties of hydrogen fuel.
\end{abstract}

Keywords: Liquefied Petroleum Gas, $L P G, L P G+\mathrm{H}_{2}$, Common-Rail

\section{INTRODUCTION}

Many researchers have focused on the use of gas fuels as alternative fuels in engines [1]. When gas fuels are used in diesel engines in as a dual fuel, some improvement in engine performance is observed, while smoke emissions are reduced [2]. They exhibit low heat and high thermal efficiency, especially under full load or high load operating conditions (peak loads) [3]. Gas fuels can be used in diesel engines in a variety of ways. These are: timed spraying in the manifold, direct spraying into the cylinder, and continuous spraying into the manifold [3]. The method of spraying directly into the combustion chamber is a method of injecting gases into the combustion chamber directly which may lead injectors to corrode [3]. In addition, more special injectors and some modifications to the cylinder head are required. In continuous manifold spraying method; flame spatter, knocking, pre-ignition problems may be encountered. With the aid of an ECU, the injection of gas into the air sucked from the intake manifold by injectors and the ignition of the gas fuel by some pilot injection are the most effective methods, and almost all of the studies in the literature have used gas fuels in diesel engines with this method.

LPG (liquefied petroleum gas) is a clean energy source for future diesel engines and can be produced from alternative energy sources [4]. LPG is also an excellent and economical fuel for exhaust emissions and engine performance [1]. Thanks to the high self-ignition temperature of LPG fuels, they can be easily used as a dual fuel by spraying in manifolds in diesel engines [5]. The easiest and most reliable method of using LPG or other gas fuels in diesel engines is to inject the gas fuel into the intake manifold and then carry out the flammability by pilot injection with the engine in small quantities [3]. Because LPG has a self-ignition temperature of $788 \mathrm{~K}$, it requires an ignition source [6]. Diesel fuel is well suited for ignition with a self-ignition temperature of $525 \mathrm{~K}$, making it the most effective method in practice for pilot injection[3]. LPG and diesel fuel have flame velocities of $4.8 \mathrm{~cm} / \mathrm{s}$ and $5.12 \mathrm{~cm} / \mathrm{s}$ at 1.6 air excess coefficient, respectively. With high flame speed and diffusion coefficient, the use of LPG fuel in engines with a small amount of pilot injection will increase combustion efficiency as it will consume more $\mathrm{O}_{2}$ during combustion and cause more oxidation [3]. In view of the literature results, it is generally evident that reduced $\mathrm{HC}$ and $\mathrm{CO}$ emissions is the result [3]. 
LPG is a clean fuel consisting of butane and propane mixture gases [1]. However, from the literature, LPG's gas composition changes significantly affect emissions and engine efficiency [7]. The propane / butane ratio of LPG fuel varies from country to country. Propane / butane mixtures at different ratios affect the combustion process and exhaust emissions [8].

Lata et al. [3] used a 4-cylinder, turbocharged and intercooler diesel engine generator setting with 62.5 kw power. LPG and $\mathrm{H}_{2}$ / LPG fuels of various gas ratios were sent from the intake manifold and ignited by pilot injection. In thermal efficiency, a maximum $6 \%$ efficiency increase was observed with the use of LPG instead of diesel as $40 \%$ energy content. Compared to diesel only, $\mathrm{HC}$ and $\mathrm{CO}$ increased a little; $\mathrm{NO}_{\mathrm{x}}$ and smoke emissions have decreased somewhat. When LPG / $\mathrm{H}_{2}\left(70 \% \mathrm{LPG}, 30 \% \mathrm{H}_{2}\right.$ by volume) was used as energy content instead of $40 \%$ diesel, a $27 \%$ increase in thermal efficiency and a $68 \%$ decrease in HC were observed [3]. It has been found that thermal efficiency is increased when using gas LPG or LPG / $\mathrm{H}_{2}$ fuels only in situations above $10 \%$ load [3]. The reason for this is the increase in ignition delay and the increase in flame-out zones, which reduces the combustion efficiency and decreases the thermal efficiency. Also, at high loads $(>60 \%)$, use of over $70 \%$ of LPG is defined as the knock limit.

Poonia et al. [7] experimentally examined the effect of intake air temperature, the amount of pilot injected diesel and the amount of EGR on the performance and emissions of the diesel operating with the engine / LPG mixture fuel. It was found that the HC emission increased as the pilot injection amount increased. Optimization in the heating of EGR and intake air led to a slight increase in thermal efficiency and a decrease in HC. Vijayabalan et al. [9] studied the single-cylinder, air-cooled engine by spraying the pilot diesel and by spraying LPG from the intake manifold. The decrease in $\mathrm{NO}_{\mathrm{x}}$ emissions is observed at all load stages. In dual fuel usage, higher emissions of $\mathrm{CO}$ and $\mathrm{HC}$ emissions are evident and thermal efficiency is reduced due to poor ignition under low load conditions. By putting glow plugs in the combustion chamber, this problem is solved which became evident at low loads. In this case, under low load conditions, a 3\% efficiency increase, a decrease in $69 \% \mathrm{HC}, 50 \% \mathrm{CO}$ and $9 \%$ smoke emissions was found, but no change in $\mathrm{NO}_{\mathrm{x}}$ emissions was observed. Zhili has found that low $\mathrm{NO}_{\mathrm{x}}$ and high thermal efficiency can be achieved by adding LPG and di-methyl ether to a diesel engine. Selim [10] et al. tested LPG and CNG using the diesel fuel and Jojoba methyl ester (JME) as pilot fuel in the Ricardo E6 CFR setane engine. As a result of the studies; the maximum pressure increase rate was found to be higher in LPG or CNG additional fuel engines. The maximum pressure increase was found to be as follows: diesel / LPG, diesel / CNG, JME / LGP, JME / CNG. Emission values of CO and HC emissions were found to be as follows: JME / LPG, JME / CNG, diesel / LPG, diesel / CNG. Furthermore, a high amount of LPG fuel was observed to be knocking at high compression ratios and under full load. Qi [5] used mixtures of LPG at $0 \%, 10 \%, 20 \%, 30 \%$ and $40 \%$ mass in a direct injection diesel engine, the effect of LPG as an additional fuel on emissions and engine performance is investigated. In the test results, it was found that with the increase of LPG, the decrease of the pressure inside the peak cylinder and the increase of the ignition delay is obtained. As LPG is used as additional fuel at low speed, there is a slight increase in heat emission rate and a slight decrease in combustion duration; using over 20\% LPG at high speeds; the heat dissipation rate is reduced and the combustion time is prolonged. A slight increase in $\mathrm{HC}$ and $\mathrm{CO}$ emissions has been observed when there is some decrease in the use of LPG as an additional fuel in $\mathrm{NO}_{\mathrm{x}}$ and smoke emissions. A slight increase in specific fuel consumption has also been observed, but LPG is projected to be a more economical alternative fuel with a lower price [5].

Hydrogen, carbon-free, with superior combustion properties and being an environmentally friendly fuel. Like electricity, it is an excellent energy carrier in $\mathrm{H}_{2}$ [11]. Moreover, $\mathrm{H}_{2}$ can be produced from renewable energy sources. Gasoline engines are well suited for $\mathrm{H}_{2}$ conversion, but can also be used in $\mathrm{H}_{2}$ diesel engines with some simple modifications [12]. Due to the high self-ignition temperature of $\mathrm{H}_{2}\left(576^{\circ} \mathrm{C}\right)$, it is difficult to use directly in diesel engines. They need a number of ignition sources [13]. $\mathrm{H}_{2}$ is injected into the air sucked from the intake manifold in the diesel engines and the ignition is carried out by pilot injection with a small amount of diesel fuel. $\mathrm{H}_{2}$ is the easiest and most reliable method of application for diesel engines [11].

$\mathrm{H}_{2}$ has a wide flammability range and a high combustion rate, making diesel / $\mathrm{H}_{2}$ dual fuel more superior [3]. Moreover, since $\mathrm{H}_{2}$ has a high adiabatic flame rate, thermodynamics allows the cycle to approach the ideal conditions more closely [14]. Due to the high diffusion rate of $\mathrm{H}_{2}\left(0.61 \mathrm{~cm}^{2} / \mathrm{s}\right)$, air and $\mathrm{H}_{2}$ can form a better mixture.

In diesel engines, $\mathrm{H}_{2}$ fuel is usually injected during the intake stroke in the intake manifold, and as described above for the use of LPG fuel in diesel engines, the pilot diesel ignition is the most reliable and simple 
method [15]. Saravan et al. [16] used $\mathrm{H}_{2}$ fuel by pilot injection with a stationary diesel engine, engine fuel. It has been observed that a lower amount of water, particulate matter and $\mathrm{NO}_{\mathrm{x}}$ are released. With the increase in thermal efficiency, less fuel consumption is achieved. Liew et al. [17] have examined the use of $\mathrm{H}_{2}$ as an additional fuel in a diesel engine. It has been observed that by using $\mathrm{H}_{2}$ in high amounts and at high loads, the intracellular pressures and heat dissipation are increased. Furthermore, the 2-step combustion process has been found to turn into a 3-phase combustion process by using $\mathrm{H}_{2}$ as an additional fuel. In another study by Saravan [18] and others, they sprayed $\mathrm{H}_{2}$ on a single-cylinder diesel engine intake manifold. At a $75 \%$ load condition, they found that the $\mathrm{H}_{2}$ / diesel increased the efficiency of the dual fuel by $15 \%$. In general, significant reductions were observed in emissions, but only an increase of $1-2 \%$ was observed in $\mathrm{NO}_{\mathrm{x}}$ emissions. Bretti [19] modified the diesel engine to deliver diesel injectors both $\mathrm{H}_{2}$ and diesel. The average effective pressure increased from 25 bar to 35 bar and the thermal efficiency increased by $40 \%$. Lilik [20] et al. have investigated the use of $\mathrm{H}_{2}$ as an additional fuel in a 4-cylinder, turbocharged, common-rail engine at $0 \%, 2.5 \%, 5 \%, 7.5 \%, 10 \%$ and $15 \%$ of the energy content. Emissions and engine performance at engine speeds of 1800 and $3600 \mathrm{rpm}$ were investigated in a $25 \%$ and $75 \%$ load range. It has been observed that the engine has a significant amount of injection delay in its own ECU. All emissions, especially $\mathrm{NO}_{\mathrm{x}}$, have declined significantly. It is also found that the $\mathrm{NO} / \mathrm{NO}_{2}$ ratio of the released $\mathrm{NO}_{\mathrm{x}}$ emissions changes, the $\mathrm{NO}$ emissions decrease, and the $\mathrm{NO}_{2}$ emissions increase. Gomes Antunos et al. [21] observed an increase in thermal efficiency of $43 \%$ and a decrease in $\mathrm{NO}_{\mathrm{x}}$ of $20 \%$ with the use of $\mathrm{H}_{2}$ as an additional fuel for diesel engines. Bose [11] and others have sent a single-cylinder, four-stroke, diesel engine with solenoids from the intake manifold as $0.15 \mathrm{~kg} / \mathrm{h}$ of additional fuel. $(0.15 \mathrm{~kg} / \mathrm{h})$ of additional $\mathrm{H}_{2}$ is sent at constant load conditions of $20 \%, 40 \%, 60 \%$ and $80 \%$. A slight increase in $\mathrm{NO}_{\mathrm{x}}$ was observed under all operating conditions. On top of that, $10 \%$ and $20 \%$ EGR were used to reduce $\mathrm{NO}_{\mathrm{x}}$ emissions. In the case of using EGR with $\mathrm{H}_{2}$, the thermal efficiency is reduced, but it is still higher than that of diesel fuel. While significant reductions in $\mathrm{HC}, \mathrm{CO}, \mathrm{CO}_{2}$ and smoke emissions were observed, only $\mathrm{NO}_{\mathrm{x}}$ emissions were observed to increase, but $\mathrm{NO}_{\mathrm{x}}$ emissions were also controlled by EGR. Masood [22] and others have sent the diesel engine at different ratios of $\mathrm{H}_{2}$, and have fired the pilot by spraying. Problems such as difficult ignition, low power output has been overcome by the improvement of the flame extinction zone. Heffel [23] and others have sent $\mathrm{H}_{2}$ as an additional fuel to the to four-cylinder, Ford, ZETEC engine. $0.78 \mathrm{~kg} / \mathrm{h}$ and $1.63 \mathrm{~kg} / \mathrm{h} \mathrm{H} \mathrm{H}_{2}$ at $1500 \mathrm{rpm}$ engine speed with EGR. Experimental results have been observed to improve on all emissions, primarily $\mathrm{NO}_{x}$. Saravan [24] and others have reported that they have been working together with EGR in a diesel engine, sending $20 \mathrm{~L} / \mathrm{min}_{2}$ as additional fuel. Decrease in all emissions was observed, especially in the case of smoke, particulate, $\mathrm{NO}_{\mathrm{x}}$ emissions. Varde and Frame [25] on their direct-injection, single-cylinder, diesel engine, sent $\mathrm{H}_{2}$ as an additional fuel and reduced work emissions. Using 12.5\% hydrogen (energy basis), thermal efficiency increased from $30.5 \%$ to $33.7 \%$. However, when $\mathrm{H}_{2}$ with a small energy content of $5 \%$ is added, the thermal efficiency decreases. The reason is thought to be flame propagation is not fully realized because of the very poor $\mathrm{H}_{2} /$ air mixture. By using $\mathrm{H}_{2}$ as an additional fuel, the thermal efficiency is increased by reducing the combustion phase and by shortening it to a shorter period of time. Shirk et al. [26] and others have investigated the effect of diesel replacement of $5 \%$ and $10 \%$ energy content on the common-rail engine on thermal efficiency and exhaust emissions. All emissions, especially $\mathrm{NO}_{\mathrm{x}}$, have been observed to decrease.

In most of the studies carried out, only LPG fuel was used as supplementary gas fuel, or only hydrogen was used as supplementary gas fuel. The effect of diesel, LPG (30\% propane and $70 \%$ butane) and hydrogen combustion were experimentally investigated in the study. On the other hand, the addition a very low amount of hydrogen fuel into LPG fuel (20\% hydrogen by volume of the total gas fuel) and its effect on CO, THC, $\mathrm{NO}_{\mathrm{x}}$ and smoke emissions are investigated. Thanks to unique properties of hydrogen, the combustion efficiency was improved in the study. Also, the engine brake torque was kept at $70 \mathrm{Nm}$ and the brake engine speed was fixed at $1200 \mathrm{rpm}$. For this reason, the effect of different levels of gaseous fuel $\left(\mathrm{LPG}+\mathrm{H}_{2}\right)$ addition was investigated at constant brake engine speed and constant brake engine torque differently from other studies.

\section{TEST SETUP}

Figure 1 gives a schematic view of the test setup. Tests were carried out on a CI engine with single cylinder, 4 strokes, naturally aspirated, common rail fuel system. The CI engine, which is normally a mechanical fuel system, has been turned into a common rail system by using the engine control unit developed by us and placing appropriate electromagnetic injectors. In the tests, the rail pressure of the common-rail system was fixed at a pressure of 1000 bar. The diesel fuel used meets EN590 standards. The LPG fuel used is 30\% propane and 
$70 \%$ butane gas. A flow rate of $\mathrm{LPG}+\mathrm{H}_{2}$ gas fuel mixture was measured using a thermal gas flow meter. AVL Digas 4000 emission analyzer and AVL 415S smoke ether is used. All tests were carried out at Yildiz Technical University, Internal Combustion Engines Laboratory. All data obtained were collected with the NI 6215 daq card. An interface has been developed using LabView software and the data can be recorded as desired.

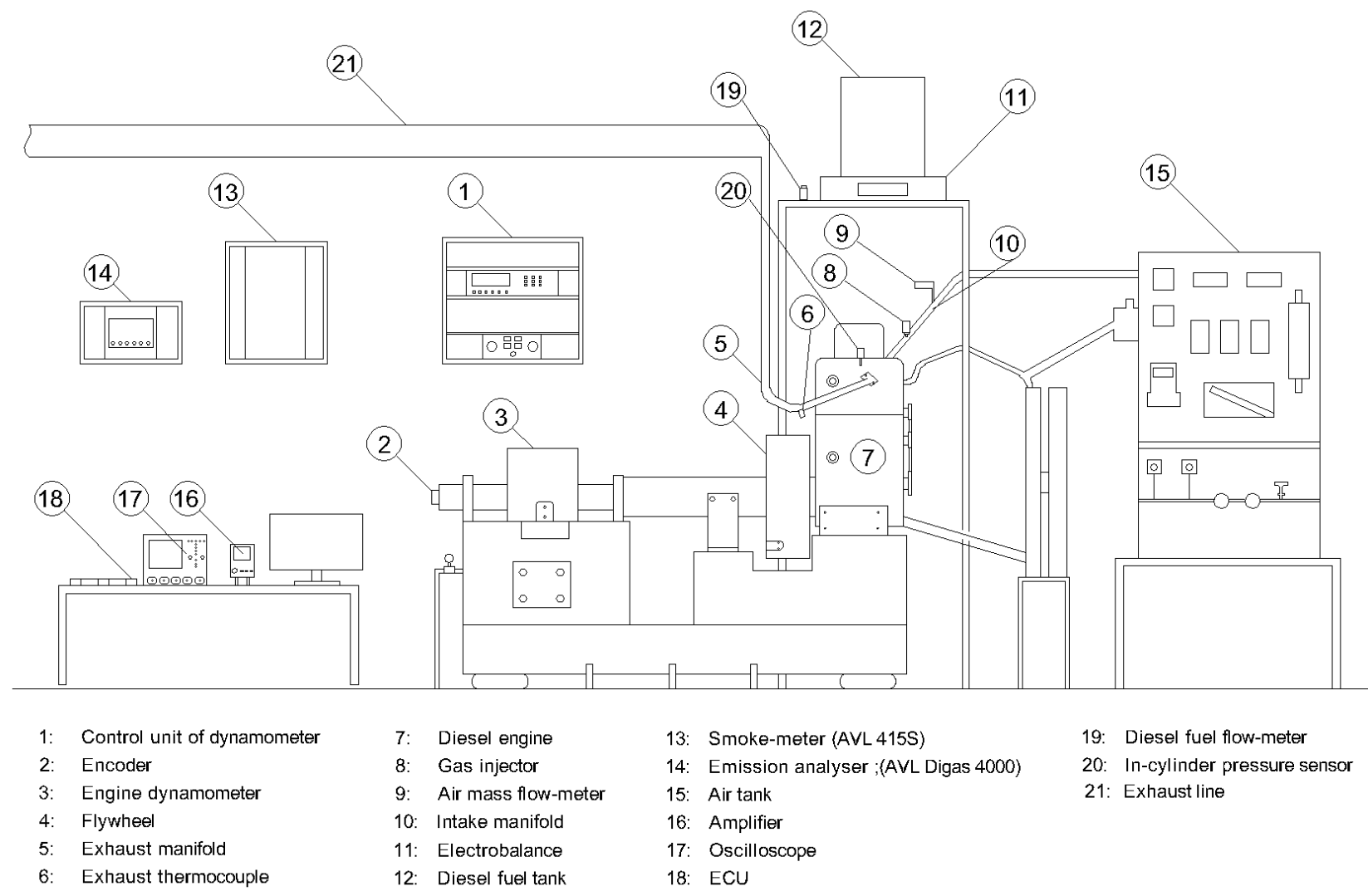

Figure 1. Test setup schematics

\section{ENGINE AND EDDY CURRENT DYNAMOMETER}

Table 1 lists the test engine specifications and dynamometer properties. Single stroke, 4 stroke, $1160 \mathrm{cc}$ cylinder capacity, Erin Motor brand, direct injection engine is used. In maximum $40 \mathrm{~kW}$ load capacity, water cooling type, CI engine was installed using Eddy current dyno. All experiments were carried out at Yildiz Technical University, Internal Combustion Engine Laboratory.

Table 1. The test engine specs and dynamometer properties

\begin{tabular}{ll}
\hline Engine brand & Erin motor \\
Aspiration method & Natural \\
Max power & $18 \mathrm{~kW} @ 2700 \mathrm{rpm}$ \\
Number of cylinders & 1 \\
Bore $\times$ stroke $[\mathrm{mm}]$ & $108 \times 127$ \\
Cylinder volume $\left[\mathrm{cm}^{3}\right]$ & 1163 \\
Compression ratio & 14.7 \\
Speed range min-max [rpm] & $800-2700$ \\
Number of intake \& exhaust & $2 \& 2$ \\
valves & \\
Cooling type & Water cooled \\
Dyno \& power $[\mathrm{kW}]$ & Eddy current \& 40 \\
\hline
\end{tabular}




\section{LPG + $\mathrm{H}_{2}$ FUEL SYSTEM}

The schematic of the LPG $+\mathrm{H}_{2}$ gas fuel system is given in Figure 2. Hydrogen and LPG are supplied separately from high pressure tanks. The hydrogen rate was fixed $20 \%$ of total gas mixture fuel (hydrogen + LPG). In all gas mixture addition cases, hydrogen rate was kept constant as $20 \%$ of total gas mixture as volume basis. Also, using needle valves after the high pressure tanks, the flow rates for both of gases were adjusted to provide $20 \%$ hydrogen rate of total gas mixture. Then, both gases are reduced to 2 bar by pressure regulator, even mixed. The flow rates of both gases are fixed with a needle valve. The flow rate of the hydrogen was fixed to be $20 \%$ by volume of the total fuel. A line regulator is installed. Then, a shut-off valve is placed on the line. What's more, even the check valve is placed on the line just before the engine, despite a possible backfiring situation. In addition, it is aimed to prevent a possible line pressure increase by placing a relief valve. In addition, it is aimed that the gas mixture flow will be made more stable by placing one high pressure resistant buffer tank. One thermal flow meter and one rotameter are located on the line. At the end of the line, a Keihin brand LPGCNG injector was installed to send gas fuel to the engine intake manifold.

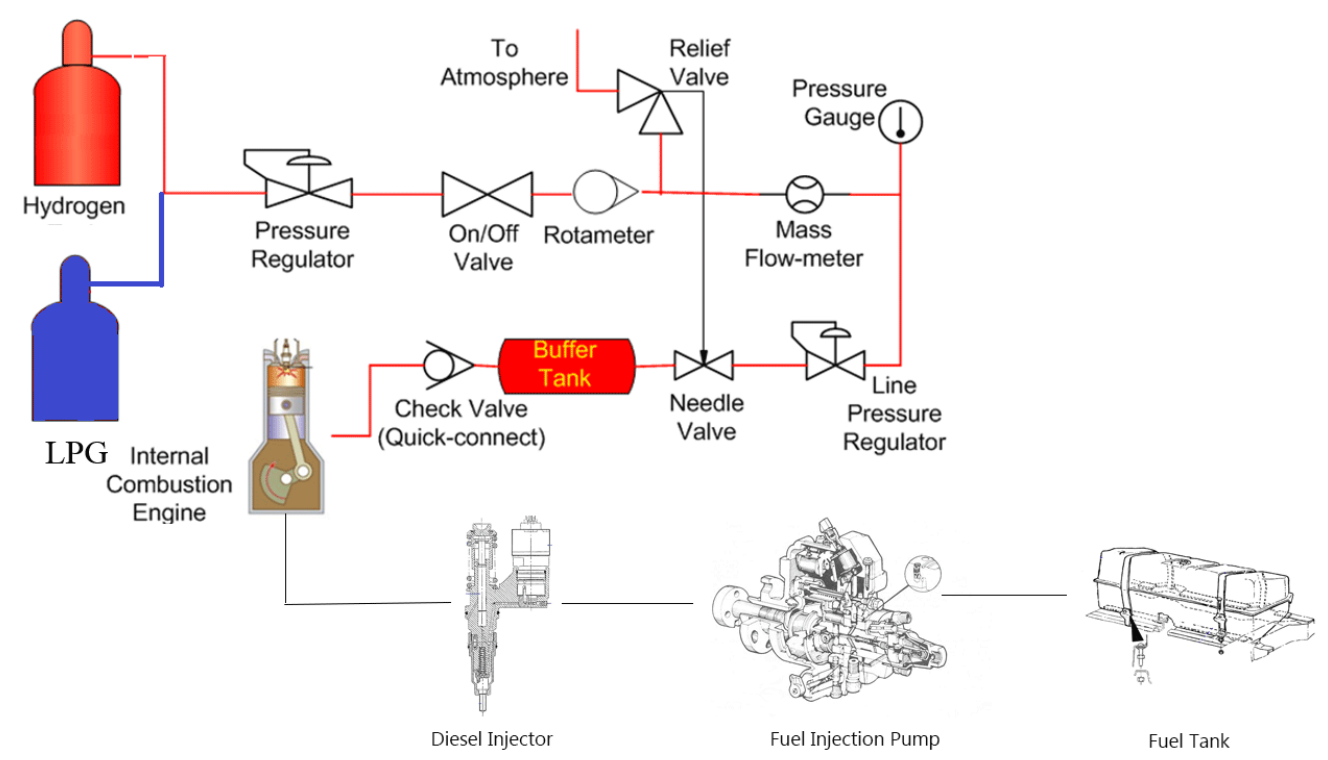

Figure 2. $\mathrm{LPG}+\mathrm{H}_{2}$ and diesel fuel system

\section{THE ENGINE CONTROL SYSTEM}

With the developed electronic control system, both diesel and gas injectors can be controlled. By means of an incremental encoder installed on the crankshaft of the engine, the engine speed and the piston position are determined, and the injectors are controlled in the determined advance and the injection quantities, and the engine is supplied with gas fuel ( $\left.\mathrm{LPG}+\mathrm{H}_{2}\right)$ or diesel fuel. The gas fuel priming advance is set to TDC in suction stroke while the diesel fuel injection advance is set to $28^{\circ} \mathrm{BTDC}$.

\section{EMISSION MEASUREMENT SYSTEMS}

Carbon monoxide, oxides of nitrogen and total unburned hydrocarbons emissions were measured with AVL Digas 4000. With the AVL 415S, smoke emission values are measured as FSN. Since the engine power and the engine speed are kept constant during operation, no specific emission is required.

\section{THE TEST CONDITIONS}

The CI engine was loaded at a constant engine speed of $1200 \mathrm{rpm}$ and at full engine load. Test conditions are given in Table 2. The effects of $\mathrm{LPG}+\mathrm{H}_{2}$ gas fuel addition on engine performance and emissions were investigated in different gas fuel energy contents $(0 \%, 15 \%, 30 \%$ and $45 \%)$. Brake engine torque value is fixed at $70 \mathrm{Nm}$ in all fuel conditions. The diesel spraying rate is fixed at $28^{\circ} \mathrm{BTDC}$. During the work, no engine knock or backfiring problem has been encountered. The uncertainty and total accuracy values are presented in Table 3. EN 590 diesel automotive fuel was used in the study. Also, the energy content means that the energy 
Journal of Thermal Engineering, Research Article, Vol. 5, No. 2, Special Issue 9, pp. 58-69, February, 2019

Table 2. The test properties summary.

\begin{tabular}{lllll}
\hline $\begin{array}{l}\text { Engine brake } \\
\text { torque }\end{array}$ & Engine speed & $\begin{array}{l}\text { Start of diesel } \\
\text { injection }\end{array}$ & $\begin{array}{l}\mathbf{L P G}+\mathbf{H}_{2} \\
\text { energy fraction }\end{array}$ & $\begin{array}{l}\text { Diesel energy } \\
\text { fraction }\end{array}$ \\
\hline $70 \mathrm{Nm}$ & $1200 \mathrm{rpm}$ & $28^{\circ} \mathrm{BTDC}$ & $0 \%$ & $100 \%$ \\
$70 \mathrm{Nm}$ & $1200 \mathrm{rpm}$ & $28^{\circ} \mathrm{BTDC}$ & $15 \%$ & $85 \%$ \\
$70 \mathrm{Nm}$ & $1200 \mathrm{rpm}$ & $28^{\circ} \mathrm{BTDC}$ & $30 \%$ & $70 \%$ \\
$70 \mathrm{Nm}$ & $1200 \mathrm{rpm}$ & $28^{\circ} \mathrm{BTDC}$ & $45 \%$ & $55 \%$ \\
\hline
\end{tabular}

Table 3. Measurement Accuracies and Total Uncertainty

\begin{tabular}{|c|c|c|}
\hline Parameter & Device & Accuracy \\
\hline Engine torque & Load cell & $\pm 0.05 \mathrm{Nm}$ \\
\hline Engine speed & $\begin{array}{l}\text { Incremental } \\
\text { Encoder }\end{array}$ & $\pm 5 \mathrm{rpm}$ \\
\hline Cylinder pressure & Kistler $6253 \mathrm{C}$ & $\pm 0.5 \%$ \\
\hline Diesel flow rate & Biotech VZS-005 & $\pm 1 \%$ [of reading] \\
\hline $\mathrm{LPG}+\mathrm{H}_{2}$ flow rate & New-Flow TMF & $\pm 1 \%$ [F.S.] \\
\hline $\mathrm{CO}$ & AVL DiCom 4000 & $0.01 \%$ Vol. \\
\hline THC & AVL DiCom 4000 & $1 \mathrm{ppm}$ \\
\hline $\mathrm{NO}_{\mathrm{x}}$ & AVL DiCom 4000 & $1 \mathrm{ppm}$ \\
\hline Smoke & AVL 415S & $0.4 \%$ Vol. \\
\hline Calculated results & & Uncertainty value \\
\hline Engine power & \multicolumn{2}{|c|}{ $\pm 0.28 \%$} \\
\hline Thermal efficiency & \multicolumn{2}{|c|}{$\begin{array}{l} \pm 1.10 \div 1.51 \% \\
{\left[0 \% \div 45 \% \mathrm{LPG}+\mathrm{H}_{2}\right]}\end{array}$} \\
\hline
\end{tabular}

ratio of gas mixture to the total fuel mixture (diesel + gas mixture (LPG + Hydrogen)). Using lower heating values of fuels, the energy flow rates of fuels was calculated.

\section{RESULTS AND DISCUSSION}

The effect of the LPG $+\mathrm{H}_{2}$ gas mixture addition $(0 \%, 15 \%, 30 \%$ and $45 \%)$ on brake thermal efficiency, $\mathrm{CO}, \mathrm{THC}, \mathrm{NO}_{\mathrm{x}}$ and smoke emissions in different energy contents at $1200 \mathrm{rpm}$ constant engine speed and $100 \%$ brake engine load investigated experimentally on the work [30-32]. The gas fuel mixture was sent through the suction manifold through the LPG-CNG injector at the suction stroke. On the other hand, the CI engine converted to a common-rail fuel system, the injection rate of the electromagnetic diesel injector is controlled by a self-developed ECU like a gas injector.

The brake thermal efficiency is obtained by dividing the obtained engine power value by the fuel energy consumed by the engine. The obtained brake thermal efficiency values are given in Figure 3 depending on the different $L P G+\mathrm{H}_{2}$ gas fuel contents. The brake thermal efficiency values decreased by $0.8 \%, 2.1 \%$ and $2.9 \%$, respectively, with the addition of $15 \%, 30 \%$ and $45 \%$ of gas fuel, respectively. The main reason for this decline in thermal efficiency is the fact that the CI engine is not designed for LPG and that the diesel injection advance is not changed. However, due to the high diffusion coefficient and high flame velocity of hydrogen in the gas fuel, this decline has remained slight. The result of the study in terms of brake thermal efficiency is similar with the results of Lata and Misra [33] in low and medium operation conditions. 


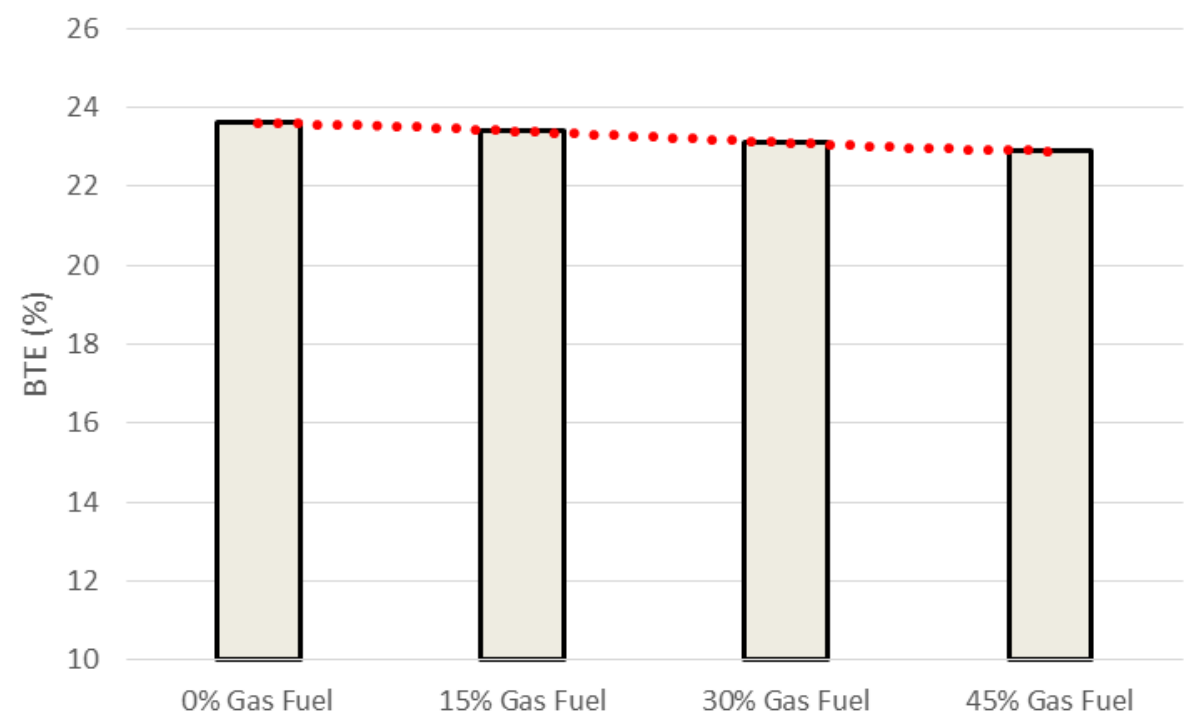

Figure 3. Effect of various level of $\mathrm{LPG}+\mathrm{H}_{2}$ addition on brake thermal efficiency

$\mathrm{CO}$ is a toxic pollutant and is quite harmful for environment and living health [27]. The main reason for the rise in $\mathrm{CO}$ emissions is the local lack of oxygen [27]. In Figure 4, the addition of $\mathrm{LPG}+\mathrm{H}_{2}$ gas fuel energy content at different ratios has been influenced on $\mathrm{CO}$ emissions. The $\mathrm{CO}$ and $\mathrm{NO}_{\mathrm{x}}$ emission levels are high for a diesel engine since a naturally aspirated CI engine was used and any after-treatment system wasn't used in the experimental study. With the addition of $15 \%, 30 \%$ and $45 \%$ gas fuel, only $4 \%, 12 \%$ and $16 \%$ increase in diesel fuel has been achieved. Normally, with the increase of gas fuels, it is expected that the regional mixture is better. However, this causes replacing gas mixtures and low volumetric efficiency especially in high speed. The greatest reason for this increase is the lack of oxygen entering the combustion chamber at the same power value due to the volume occupancy of the LPG due to the fact that hydrogen is also a gas fuel. Low oxygen content in cylinder causes to decrease combustion efficiency and $\mathrm{CO}$ emissions were increased with gaseous fuel addition. Another reason to increase in $\mathrm{CO}$ emissions is the crevices in the combustion chamber. Since the engine was designed according to diesel fuel, when using engine with gaseous fuel, the crevices causes to increase in $\mathrm{CO}$ emissions. The results of the study in terms of $\mathrm{CO}$ emission is similar with the results of the study of Lata et al. [34]. Also, Lata et al. [34] found that $\mathrm{LPG}+\mathrm{H}_{2}$ addition up to $60 \%$, the $\mathrm{CO}$ emission levels were higher than $\mathrm{LPG}$ and $\mathrm{H}_{2}$ addition at $80 \%$ engine load operating condition.

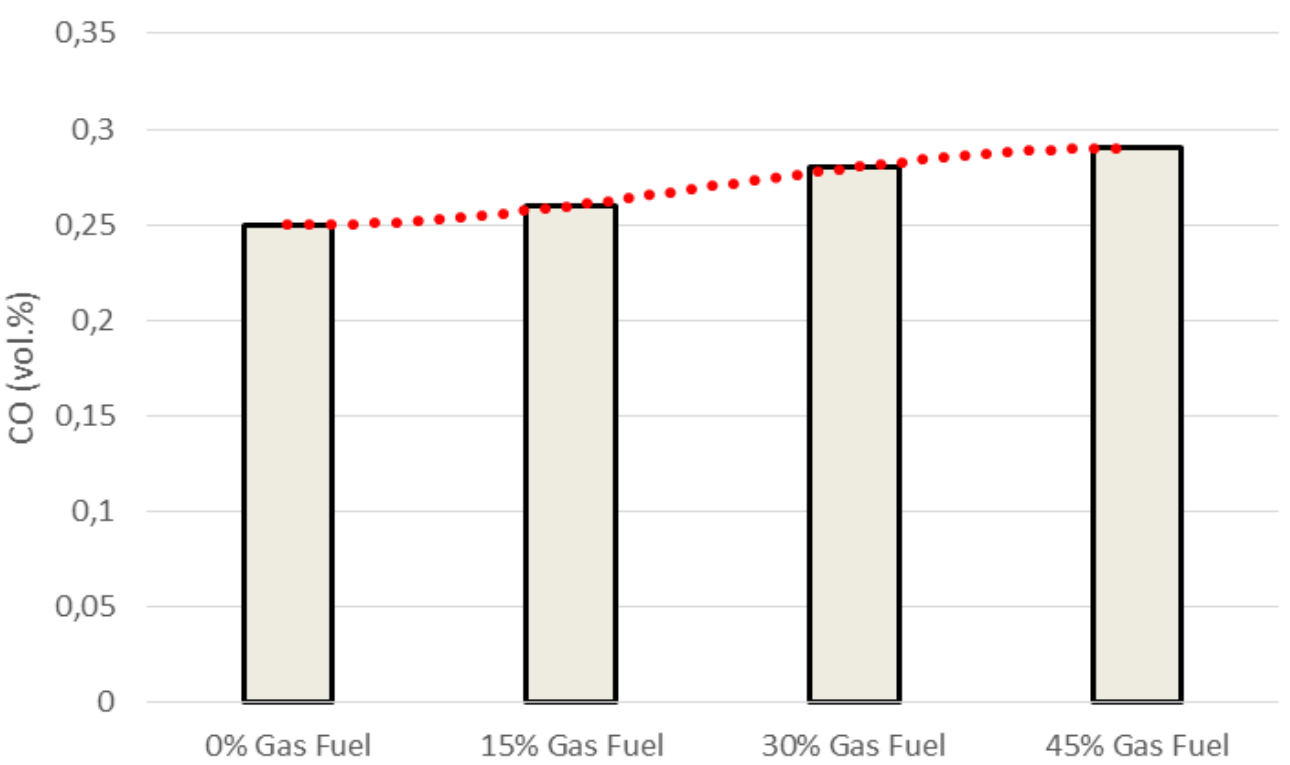

Figure 4. Effect of various level of $\mathrm{LPG}+\mathrm{H}_{2}$ addition on $\mathrm{CO}$ emissions 


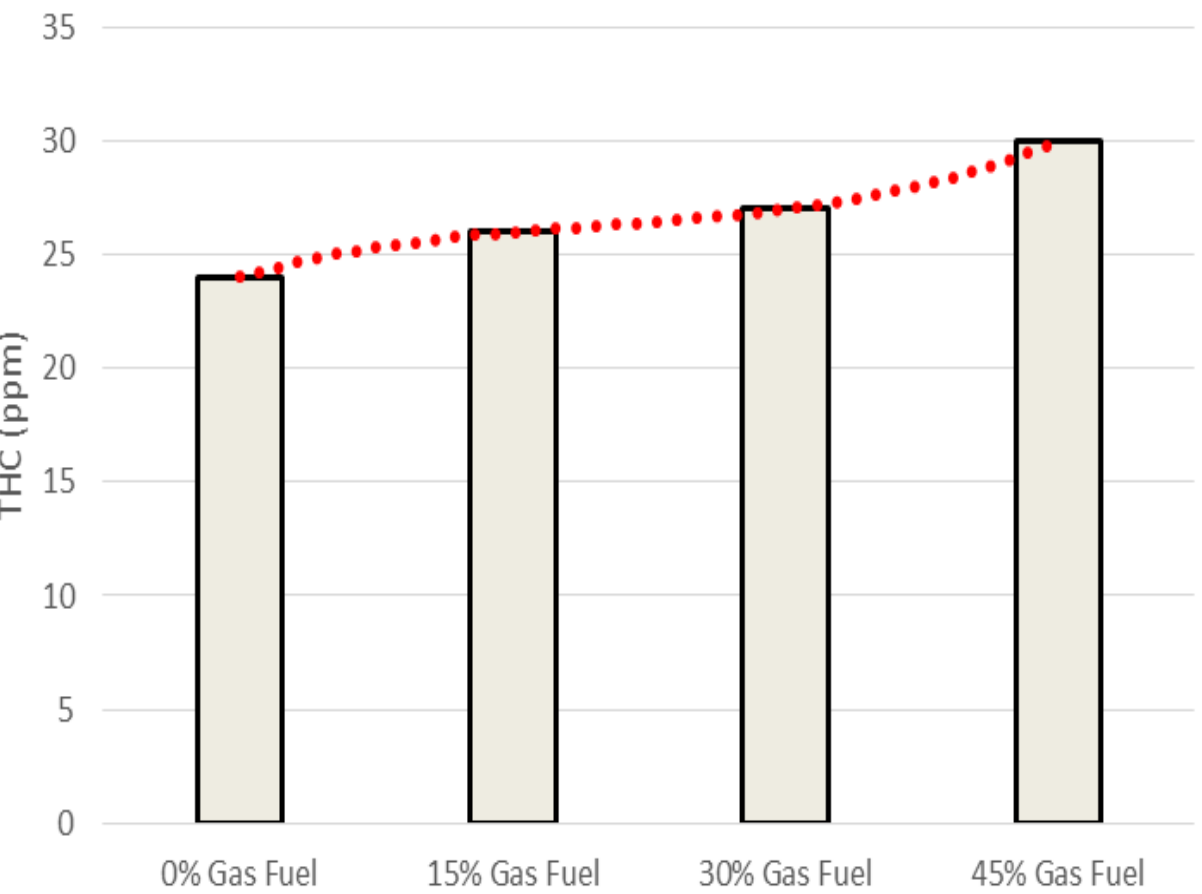

Figure 5. Effect of various level of $\mathrm{LPG}+\mathrm{H}_{2}$ addition on THC emissions

Hydrocarbon-based emissions are derived from the combustion of hydrocarbons in the fuel, either by burning or not burning [8]. Exhausted hydrocarbon emissions as a result of incomplete combustion or combustion in engines are called total hydrocarbons [8]. Figure 5 shows the effect of addition of gas fuel (LPG + $\mathrm{H}_{2}$ ) with different energy contents $(0 \%, 15 \%, 30 \%$ and $45 \%)$ on THC emissions. With the addition of $15 \%, 30 \%$ and $45 \% \mathrm{LPG}+\mathrm{H}_{2}$, the results obtained show an increase of $8.3 \%, 12.5 \%$ and $25 \%$ of THC emissions. The greatest reason for this increase in THC emissions is that the engine is not designed for LPG and $\mathrm{H}_{2}$ gas fuels and THC emissions are accumulated there during combustion and are thrown out of the engine due to the excess of the engine crevice. Lata et al. [34] found that the addition of LPG+H2 causes to increase THC emissions. For this reason, the result of the study is similar with the results of Lata et al. [34] for low engine load. Also, in high engine load an instability was observed on the study of Late et al. [34] in terms of THC emissions.

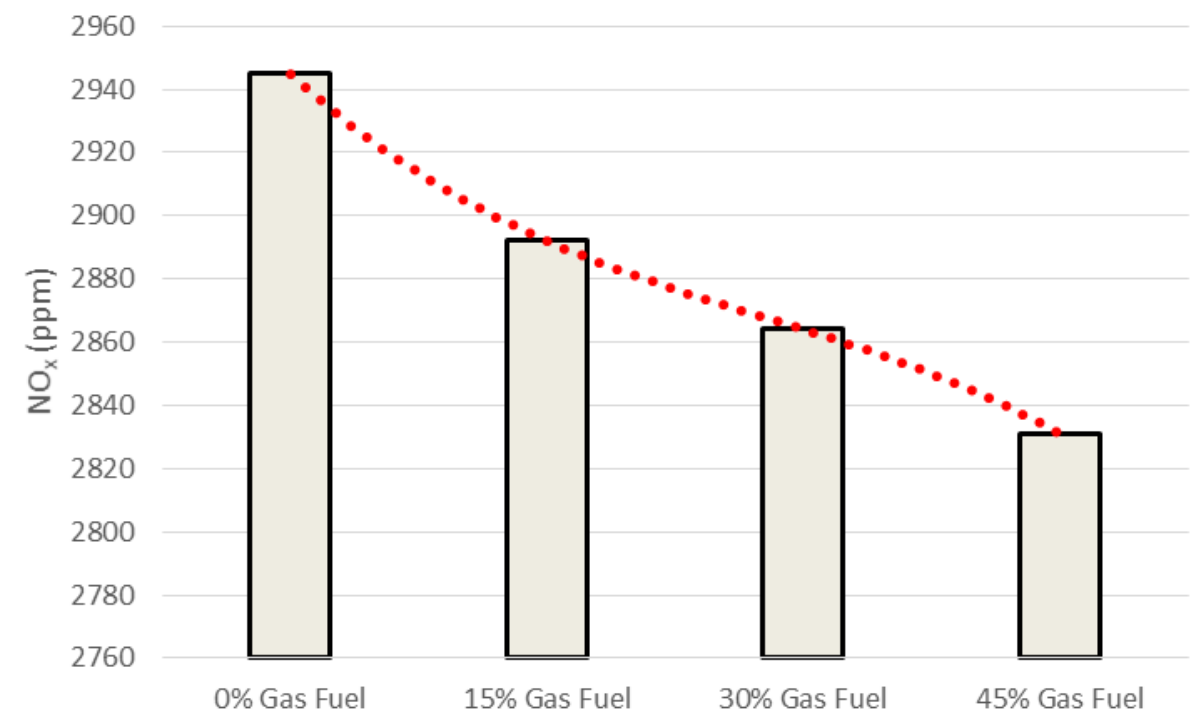

Figure 6. Effect of various level of $\mathrm{LPG}+\mathrm{H}_{2}$ addition on $\mathrm{NO}_{\mathrm{x}}$ emission 
Nitrogen oxides are formed by nitric monoxide and nitrogen dioxide gases. It is quite poisonous and harmful. They are explained by two different mechanisms [28, 29]. These are Zeldovich mechanism and Fenimore mechanism. In diesel engines, NO emissions are high. The main reason for this is that the diesel engines operate in lean conditions and the pressure inside the cylinder and therefore the temperature is high. The effect of the addition of gas fuel ( $\left.\mathrm{LPG}+\mathrm{H}_{2}\right)$ at different ratios $(0 \%, 15 \%, 30 \%$ and $45 \%)$ on $\mathrm{NO}_{\mathrm{x}}$ emissions is given in Figure 6. From the results obtained, $\mathrm{NO}_{\mathrm{x}}$ emissions decreased by $1.8 \%, 2.8 \%$ and $3.9 \%$ with addition of $\mathrm{LPG}+\mathrm{H}_{2}$ as energy content of $15 \%, 30 \%$ and $45 \%$, respectively. This result is a decrease in the amount of oxygen due to the air entering the combustion chamber due to the gas fuel covering the volume in the cylinder. Gaseous fuel acts like EGR due to lack of oxygen. Lata et al. [34] found similar results at high loads with the study in terms of $\mathrm{NO}_{\mathrm{x}}$ emissions.

One of the most important emission problems in $\mathrm{CI}$ engines is the formation of carbonaceous-originated smoke emission. They are also generally derived from oxygen deficiency and are one of the most demanding emission types for engine manufacturers in emission regulation [8]. The variation in smoke emissions due to the addition of different $\mathrm{LPG}+\mathrm{H}_{2}$ gas fuels is given in Figure 7. With the addition of $15 \%, 30 \%$ and $45 \% \mathrm{LPG}+\mathrm{H}_{2}$, the results were only $13.6 \%, 20.3 \%$ and $28.8 \%$ lower than diesel fuel, respectively. The improvement in these smoke emissions is caused by the high diffusion coefficient of gas fuels. In addition, the absence of hydrogen carbon atoms and high flame speed caused smoke emissions to be released. The addition of LPG $+\mathrm{H}_{2}$ mixtures to diesel fuel can be studied at different rates to see the effects of gas mixtures on the performance and emission as an additional study. Lata et al. [35] found that the combustion efficiency was increased with LPG $+\mathrm{H} 2$ addition. Improvement in combustion efficiency causes to decrease in smoke emissions. The results of Lata et al. [34] are similar with the study in terms of smoke emissions. Lata et al. [34] found that increasing amount of gaseous fuel ( $\mathrm{LPG}, \mathrm{LPG}+\mathrm{H}_{2}, \mathrm{H}_{2}$ ) causes to decrease of smoke emissions.

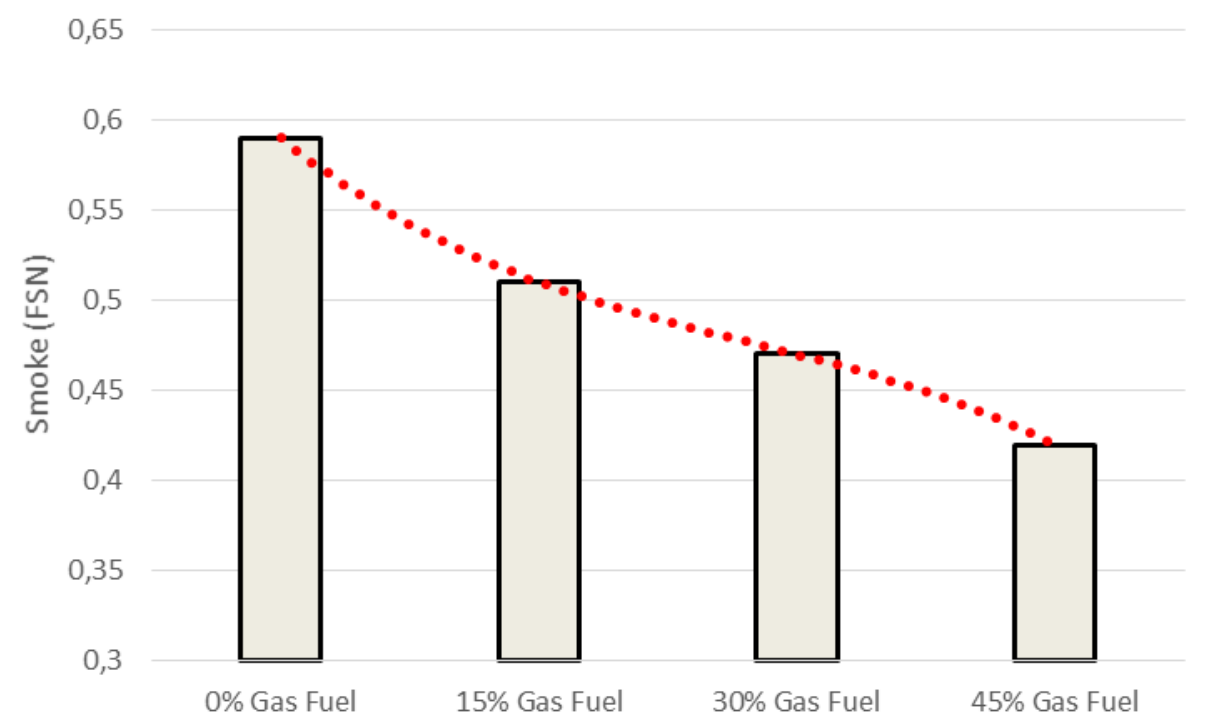

Figure 7. Effect of various level of $\mathrm{LPG}+\mathrm{H}_{2}$ hydrogen addition on smoke emission

\section{CONCLUSION}

The effect of LPG $+\mathrm{H}_{2}$ addition on engine performance and emissions in different energy contents $(0 \%$, $15 \%, 30 \%$ and $45 \%$ ) at a constant brake engine torque of $70 \mathrm{Nm}$ was investigated at $1200 \mathrm{rpm}$ engine speed. The hydrogen ratio in the gas fuel mixture was kept constant $20 \%$ of the total gas fuel by volume. The effect of different levels of hydrogen addition on engine performance and emissions were experimentally investigated. The results obtained are given below.

- The BTE decreased by $0.8 \%, 2.1 \%$ and $2.9 \%$ respectively with addition of $15 \%, 30 \%$ and $45 \%$ LPG + hydrogen compared to neat diesel fuel.

- CO emissions increased by $4 \%, 12 \%$ and $16 \%$, respectively with $15 \%, 30 \%$ and $45 \%$ LPG + hydrogen addition compared to neat diesel fuel. 
- THC emissions increased by $8.3 \%, 12.5 \%$ and $25 \%$ with $15 \%, 30 \%$ and $45 \%$ LPG + hydrogen addition compared to neat diesel.

- $\mathrm{NO}_{\mathrm{x}}$ emissions improved by $1.8 \%, 2.8 \%$ and $3.9 \%$ with $15 \%, 40 \%$ and $75 \% \mathrm{LPG}+$ hydrogen addition.

- Smoke emissions improved by $13.6 \%, 20.3 \%$ and $28.8 \%$ with $15 \%, 40 \%$ and $75 \%$ LPG + hydrogen addition compared with neat diesel fuel.

- Using LPG + Hydrogen as additional fuel, the inversely proportional $\mathrm{NO}_{\mathrm{x}}$ emissions and smoke emission were decreased simultaneously.

- Lastly, using small amount of hydrogen in gas mixture (LPG + Hydrogen) as additional fuel in diesel engines can be a solution to extinguish detrimental effects of diesel engines.

In the future works, the effect of micro pilot diesel injection and high rates of gas fuel mixture (LPG + Hydrogen) addition on emissions, performance and combustion characteristics of diesel engine will be studied.

\section{ACKNOWLEDGEMENT}

This research was supported by TÜBITAK (Scientific and Technological Research Council of Turkey) with 1512 project. Project Number: 2150175. The author is also indebted to Şahin Metal A.Ş. and Erin Motor for test apparatus and equipment donation.

\section{NOMENCLATURE}

$\begin{array}{ll}\mathrm{CI} & \text { Compression ignition } \\ \mathrm{CNG} & \text { Compressed natural gas } \\ \mathrm{CO} & \text { Carbon monoxide } \\ \mathrm{CO}_{2} & \text { Carbon dioxide } \\ \mathrm{ECU} & \text { Electronic control unit } \\ \mathrm{H}_{2} & \text { Hydrogen } \\ \mathrm{HC} & \text { Hydrocarbons } \\ \mathrm{LPG} & \text { Liquefied petroleum gas } \\ \mathrm{NO}_{\mathrm{x}} & \text { Oxides of nitrogen } \\ \text { THC } & \text { Total unburned hydrocarbons }\end{array}$

\section{REFERENCES}

[1] Saleh, H. E. (2008). Effect of variation in LPG composition on emissions and performance in a dual fuel diesel engine. Fuel, 87(13-14), 3031-3039.

[2] Kumar, M. S., Ramesh, A., \& Nagalingam, B. (2003). Use of hydrogen to enhance the performance of a vegetable oil fuelled compression ignition engine. International Journal of Hydrogen Energy, 28(10), 1143-1154. [3] Lata, D. B., Misra, A., \& Medhekar, S. (2012). Effect of hydrogen and LPG addition on the efficiency and emissions of a dual fuel diesel engine. International Journal of Hydrogen Energy, 37(7), 6084-6096.

[4] Beroun, S., \& Martins, J. (2001). The development of gas (CNG, LPG and H2) engines for buses and trucks and their emission and cycle variability characteristics (No. 2001-01-0144). SAE Technical Paper.

[5] Qi, D. H., Bian, Y. Z., Ma, Z. Y., Zhang, C. H., \& Liu, S. Q. (2007). Combustion and exhaust emission characteristics of a compression ignition engine using liquefied petroleum gas-diesel blended fuel. Energy Conversion and Management, 48(2), 500-509.

[6] Sahoo, B. B., Sahoo, N., \& Saha, U. K. (2009). Effect of engine parameters and type of gaseous fuel on the performance of dual-fuel gas diesel engines-A critical review. Renewable and Sustainable Energy Reviews, 13(6-7), 1151-1184.

[7] Poonia, M. P., Ramesh, A., \& Gaur, R. R. (1999). Experimental investigation of the factors affecting the performance of a LPG-diesel dual fuel engine. SAE transactions, 499-508.

[8] Heywood JB. Internal combustion egine fundementals. (1988).New York:McGraw-Hill.

[9] Vijayabalan, P., \& Nagarajan, G. (2009). Performance, emission and combustion of LPG diesel dual fuel engine using glow plug. JJMIE, 2, 105-110.

[10] Selim, M. Y., Radwan, M. S., \& Saleh, H. E. (2008). Improving the performance of dual fuel engines running on natural gas/LPG by using pilot fuel derived from jojoba seeds. Renewable Energy, 33(6), 1173-1185. 
[11] Bose, P. K., \& Maji, D. (2009). An experimental investigation on engine performance and emissions of a single cylinder diesel engine using hydrogen as inducted fuel and diesel as injected fuel with exhaust gas recirculation. International Journal of Hydrogen Energy, 34(11), 4847-4854.

[12] Das, L. M. (2002). Hydrogen engine: research and development (R\&D) programmes in Indian Institute of Technology (IIT), Delhi. International journal of hydrogen energy, 27(9), 953-965.

[13] Das, L. M. (2002). Near-term introduction of hydrogen engines for automotive and agricultural application. International Journal of Hydrogen Energy, 27(5), 479-487.

[14] Boretti, A. (2011). Advantages of the direct injection of both diesel and hydrogen in dual fuel H2ICE. International Journal of Hydrogen Energy, 36(15), 9312-9317.

[15] Liew, C., Li, H., Nuszkowski, J., Liu, S., Gatts, T., Atkinson, R., \& Clark, N. (2010). An experimental investigation of the combustion process of a heavy-duty diesel engine enriched with H2. International Journal of Hydrogen Energy, 35(20), 11357-11365.

[16] Saravanan, N., \& Nagarajan, G. (2008). An experimental investigation of hydrogen-enriched air induction in a diesel engine system. International Journal of Hydrogen Energy, 33(6), 1769-1775.

[17] Liew, C., Li, H., Nuszkowski, J., Liu, S., Gatts, T., Atkinson, R., \& Clark, N. (2010). An experimental investigation of the combustion process of a heavy-duty diesel engine enriched with $\mathrm{H} 2$. International Journal of Hydrogen Energy, 35(20), 11357-11365.

[18] Saravanan, N., \& Nagarajan, G. (2010). Performance and emission studies on port injection of hydrogen with varied flow rates with Diesel as an ignition source. Applied Energy, 87(7), 2218-2229.

[19] Szwaja, S., \& Grab-Rogalinski, K. (2009). Hydrogen combustion in a compression ignition diesel engine. International Journal of Hydrogen Energy, 34(10), 4413-4421.

[20] Lilik, G. K., Zhang, H., Herreros, J. M., Haworth, D. C., \& Boehman, A. L. (2010). Hydrogen assisted diesel combustion. International Journal of Hydrogen Energy, 35(9), 4382-4398.

[21] Antunes, J. G., Mikalsen, R., \& Roskilly, A. P. (2009). An experimental study of a direct injection compression ignition hydrogen engine. International journal of hydrogen energy, 34(15), 6516-6522.

[22] Masood, M., Ishrat, M. M., \& Reddy, A. S. (2007). Computational combustion and emission analysis of hydrogen-diesel blends with experimental verification. International Journal of Hydrogen Energy, 32(13), 25392547.

[23] Heffel, J. W. (2003). NOx emission and performance data for a hydrogen fueled internal combustion engine at 1500rpm using exhaust gas recirculation. International Journal of Hydrogen Energy, 28(8), 901-908.

[24] Saravanan, N., Nagarajan, G., Kalaiselvan, K. M., \& Dhanasekaran, C. (2008). An experimental investigation on hydrogen as a dual fuel for diesel engine system with exhaust gas recirculation technique. Renewable Energy, 33(3), 422-427.

[25] Varde, K. S., \& Frame, G. A. (1983). Hydrogen aspiration in a direct injection type diesel engine-its effects on smoke and other engine performance parameters. International Journal of Hydrogen Energy, 8(7), 549-555.

[26] Shirk, M. G., McGuire, T. P., Neal, G. L., \& Haworth, D. C. (2008). Investigation of a hydrogen-assisted combustion system for a light-duty diesel vehicle. International Journal of Hydrogen Energy, 33(23), 7237-7244.

[27] Wei, L., \& Geng, P. (2016). A review on natural gas/diesel dual fuel combustion, emissions and performance. Fuel Processing Technology, 142, 264-278.

[28] Fenimore, C. P. (1971, January). Formation of nitric oxide in premixed hydrocarbon flames. In Symposium (International) on Combustion (Vol. 13, No. 1, pp. 373-380). Elsevier.

[29] Stiesch, G. (2003). Modeling engine spray and combustion processes. Springer Science \& Business Media.

[30] Karagöz, Y., Sandalcı, T., Koylu, U. O., Dalkılıç, A. S., \& Wongwises, S. (2016). Effect of the use of natural gas-diesel fuel mixture on performance, emissions, and combustion characteristics of a compression ignition engine. Advances in Mechanical Engineering, 8(4), 1687814016643228.

[31] Karagöz, Y., Güler, İ., Sandalcı, T., Yüksek, L., Dalkılıç, A. S., \& Wongwises, S. (2016). Effects of hydrogen and methane addition on combustion characteristics, emissions, and performance of a CI engine. International Journal of Hydrogen Energy, 41(2), 1313-1325.

[32] Karagöz, Y. (2018). Effect of hydrogen addition at different levels on emissions and performance of a diesel engine. Journal of Thermal Engineering, 4(2), 1780-1790.

[33] Lata, D. B., \& Misra, A. (2010). Theoretical and experimental investigations on the performance of dual fuel diesel engine with hydrogen and LPG as secondary fuels. International Journal of Hydrogen Energy, 35(21), 11918-11931. 
Journal of Thermal Engineering, Research Article, Vol. 5, No. 2, Special Issue 9, pp. 58-69, February, 2019

[34] Lata, D. B., Misra, A., \& Medhekar, S. (2012). Effect of hydrogen and LPG addition on the efficiency and emissions of a dual fuel diesel engine. International Journal of Hydrogen Energy, 37(7), 6084-6096.

[35] Lata, D. B., Misra, A., \& Medhekar, S. (2011). Investigations on the combustion parameters of a dual fuel diesel engine with hydrogen and LPG as secondary fuels. International Journal of Hydrogen Energy, 36(21), 13808-13819. 